\title{
Effects of mucopolysaccharides on penicillin-induced lysis of Staphylococcus aureus
}

\author{
T. KIRIYAMA*, Y. MIYAKE, M. SUGAI, K. KOBAYASHI, K. YOSHIGA*, K. TAKADA* and \\ H. SUGINAKA
}

\begin{abstract}
Department of Microbiology and Oral Bacteriology and "First Department of Oral and Maxillofacial Surgery, Hiroshima University School of Dentistry, Hiroshima 734, Japan
\end{abstract}

\begin{abstract}
Summary. Effects of four mucopolysaccharides and dextran sulphate on penicillininduced lysis of Staphylococcus aureus FDA 209P were studied. Heparin and dextran sulphate inhibited lysis, whereas hyaluronic acid enhanced it. Chondroitin sulphates $A$ and $C$ had no effect. Incubation of $S$. aureus suspended in $0.03 \mathrm{M}$ phosphate buffer $(p \mathrm{H} \mathrm{7 \cdot 0)}$ with dextran sulphate inhibited autolysis of the bacteria, whereas incubation with hyaluronic acid enhanced autolysis. Both extracellular and cell-associated autolysin activities of $S$. aureus were suppressed by dextran sulphate and high concentrations of heparin. The addition of hyaluronic acid enhanced autolysin activity. The release of lipoteichoic acid (LTA), a modulator of autolysin activity, from penicillin-treated bacteria was inhibited by heparin and dextran sulphate. However, hyaluronic acid had no effect on release of LTA.

These results suggest that inhibition of penicillin-induced lysis of $S$. aureus by heparin results mainly from inhibition of LTA release while dextran sulphate inhibits both autolysin activity and LTA release. Hyaluronic acid appears to enhance penicillin-induced lysis through activation of the autolysins.
\end{abstract}

\section{Introduction}

Infected lesions contain inflammatory exudates, leukocytes, and many other substances which may influence the antibacterial activity of antibiotics. Inflammatory exudates are rich in mucopolysaccharides and other anionic polyelectrolytes. Heparin, one such mucopolysaccharide, is used therapeutically as an anticoagulant; chondroitin sulphate is used as an accelerator of wound healing. It has been reported that leukocyte extracts and some cationic substances activate the autolytic systems of Staphylococcus aureus, whereas anionic polyelectrolytes such as heparin, dextran sulphate, suramine polyglutamic acid, and Liquoid (sodium polyanethol sulphonate) markedly inhibit autolysis (Ginsberg et al., 1976, 1982; Ne'eman et al., 1979). Because penicillin lyses bacteria by inhibition of cell-wall synthesis and activation of autolytic enzymes (Rogers, 1967; Tomasz et al., 1970; Rogers and Forsberg, 1971; Tomasz, 1974; Garcia et al., 1982), mucopolysaccharides and other anionic polyelectrolytes, which inhibit autolysis, may affect the activity of penicillin. Therefore, we investigated the effects of mucopolysaccharides and dextran sulphate on lysis of $S$. aureus by penicillin.

Received 20 Oct. 1986; revised version accepted 10 Feb. 1987.

\section{Materials and methods}

\section{Reagents}

Hyaluronic acid, chondroitin sulphates $\mathrm{A}$ and $\mathrm{C}$, and heparin were obtained as sodium salts from Nakarai Chemicals Ltd, Kyoto, Japan. Dextran sulphate was obtained from Pharmacia Fine Chemicals AB, Uppsala, Sweden.

Effects of mucopolysaccharides and dextran sulphate on penicillin-induced lysis

Exponentially growing cultures of $S$. aureus FDA 209P in Trypticase Soy Broth (TSB; BBL Microbiology Systems, Cockeysville, MD, USA) were transferred to fresh broth and mucopolysaccharide or dextran sulphate was added to achieve the required concentration. These cultures and a control culture without additive were grown at $37^{\circ} \mathrm{C}$ with shaking. The rate of change in turbidity during growth was measured at $660 \mathrm{~nm}$ in a spectrophotometer (100-10, Hitachi, Tokyo, Japan). When the absorbance reached 0.20 OD units, benzylpenicillin (Meiji Seika Ltd, Tokyo, Japan) was added to the cultures to achieve a concentration of $0.1 \mu \mathrm{g} / \mathrm{ml}$ (2 MIC) and they were further incubated. The numbers of colony forming units (cfu) at the time of antibiotic addition and after incubation for $4 \mathrm{~h}$ were determined by plating serial dilutions of the culture on to Trypticase Soy Agar. 


\section{Measurement of autolysis of whole cells}

Exponentially growing cells of $S$. aureus were thoroughly washed, suspended in $0.03 \mathrm{M}$ phosphate buffer $(p \mathrm{H} 7.0)$ to a final concentration of $0.25 \mathrm{mg}$ (wet weight) $/ \mathrm{ml}$, and incubated at $37^{\circ} \mathrm{C}$. The change in turbidity of the suspension in the presence and absence of various concentrations of mucopolysaccharides or dextran sulphate was monitored spectrophotometrically at $600 \mathrm{~nm}$. A suspension of heat-killed $S$. aureus was included as a negative control.

\section{Preparation of autolysins}

Solid ammonium sulphate was added to the culture supernate of an exponential-phase culture of $S$. aureus to achieve $75 \%$ saturation. The resulting precipitate was dissolved in $0.01 \mathrm{M}$ phosphate buffer $(p \mathbf{H} 7.0)$, dialysed against the same buffer and used as a source of extracellular autolysin. Cell-associated autolysin was prepared from exponential-phase bacteria harvested by centrifugation at $4^{\circ} \mathrm{C}$ and washed twice with saline. The cell pellet was extracted with ten times its volume of Triton X-100 $2 \%$; the suspension was centrifuged and the supernate was dialysed against distilled water. Solid ammonium sulphate was added to the dialysed supernate to achieve $75 \%$ saturation. The precipitate was collected by centrifugation, dissolved in $0.01 \mathrm{M}$ phosphate buffer $(p \mathrm{H} \mathrm{7.0)}$ and dialysed against the same buffer. This fraction was used as a source of cell-associated autolysin. The protein concentration was measured by the method of Lowry et al. (1951).

Autolysin activity was determined with heated cells of Micrococcus lysodeikticus NCTC 2665 as substrate. The autolysin fraction containing protein $300 \mu \mathrm{g} / \mathrm{ml}$ (extracellular autolysin) and $50 \mu \mathrm{g} / \mathrm{ml}$ (cell-associated autolysin) was incubated with $M$. lysodeikticus $(0.5 \mathrm{mg}$ dry weight $/ \mathrm{ml}$ ) suspended in $0.05 \mathrm{M}$ phosphate buffer $(p \mathrm{H} \mathrm{7.0)}$, and the change in turbidity of the suspension was monitored spectrophotometrically.

\section{Release of $\left[{ }^{14} \mathrm{C}\right]$-glycerol labelled lipoteichoic acid from staphylococci}

$\left[{ }^{14} \mathrm{C}\right]$-glycerol $(11.8 \mathrm{mCi} / \mathrm{mmole})$ (New England Nuclear, IL, USA) was added to an early exponentialphase culture of $S$. aureus to achieve a concentration of $2 \mu \mathrm{Ci} / \mathrm{ml}$ and incubated with shaking. The cells were harvested in the late exponential phase by centrifugation and washed twice in TSB. The washed radiolabelled cells were resuspended in fresh TSB (final turbidity of the cultures: 0.2 absorbance unit at $600 \mathrm{~nm}$ ), and incubated at $37^{\circ} \mathrm{C}$ with benzylpenicillin (final concentration $0.1 \mu \mathrm{g} /$ $\mathrm{ml}$ ) and a mucopolysaccharide or dextran sulphate. A negative control culture that contained no mucopolysaccharide or dextran sulphate and a positive control with penicillin were included. A $0 \cdot 4-\mathrm{ml}$ sample was removed $30 \mathrm{~min}$ after the addition of penicillin and centrifuged at $9000 \mathrm{~g}$ for $5 \mathrm{~min}$. The supernate $(0.2 \mathrm{ml})$ was removed, dissolved in $10 \mathrm{ml}$ of ACS II (Aqueous Counting
Scintillant; Amersham, IL, USA) and analysed in a liquid scintillation counter (type LSC-903, Aloka, Tokyo, Japan). The release of lipoteichoic acid (LTA) was determined as the cpm of the supernate.

\section{Combined antibacterial effect of penicillin with heparin, dextran sulphate or hyaluronic acid on S. aureus}

The minimum inhibitory concentration (MIC) of penicillin alone and in combination with heparin, dextran sulphate or hyaluronic acid against $S$. aureus was determined by a broth dilution method. The concentration of heparin and hyaluronic acid was in the range 100$1000 \mu \mathrm{g} / \mathrm{ml}$ and that of dextran sulphate $10-100 \mu \mathrm{g} / \mathrm{ml}$. Each concentration was tested with serial dilutions of penicillin and an inoculum of $S$. aureus of $10^{6} \mathrm{cfu} / \mathrm{ml}$. The MIC was defined as the lowest concentration of penicillin at which there was no turbidity on visual inspection after overnight incubation at $37^{\circ} \mathrm{C}$.

\section{Results}

\section{Effects of mucopolysaccharides on penicillin-induced lysis}

Addition of benzylpenicillin (final concentration $0.1 \mu \mathrm{g} / \mathrm{ml} ; 2$ MIC) to a growing culture of $S$. aureus caused marked bacteriolysis (fig. 1). Addition of heparin or dextran sulphate inhibited the penicillininduced lysis in a dose-dependent fashion, whereas lysis in the presence of hyaluronic acid was accelerated. Chondroitin sulphates $\mathrm{A}$ and $\mathrm{C}$ had no effect on lysis by penicillin. Inhibition of lysis by heparin was observed only when it was added before penicillin. However, dextran sulphate inhibited lysis even when it was added $30 \mathrm{~min}$ after penicillin (data not shown). Heparin, dextran sulphate, chondroitin sulphates, and hyaluronic acid had no effect on bacterial growth in the absence of penicillin (fig. 1).

The bactericidal effect of penicillin on $S$. aureus was slightly reduced in the presence of heparin or dextran sulphate and slightly increased in the presence of hyaluronic acid (table I). Microscopy of bacteria exposed to heparin or dextran sulphate with penicillin revealed considerable cell swelling in comparison with untreated cells (data not shown). Viability of $S$. aureus was not influenced by the addition of heparin, dextran sulphate, or hyaluronic acid alone.

\section{Effects of mucopolysaccharides on autolysis}

The turbidity of suspensions of $S$. aureus fell with time, but the fall in turbidity was not observed with 


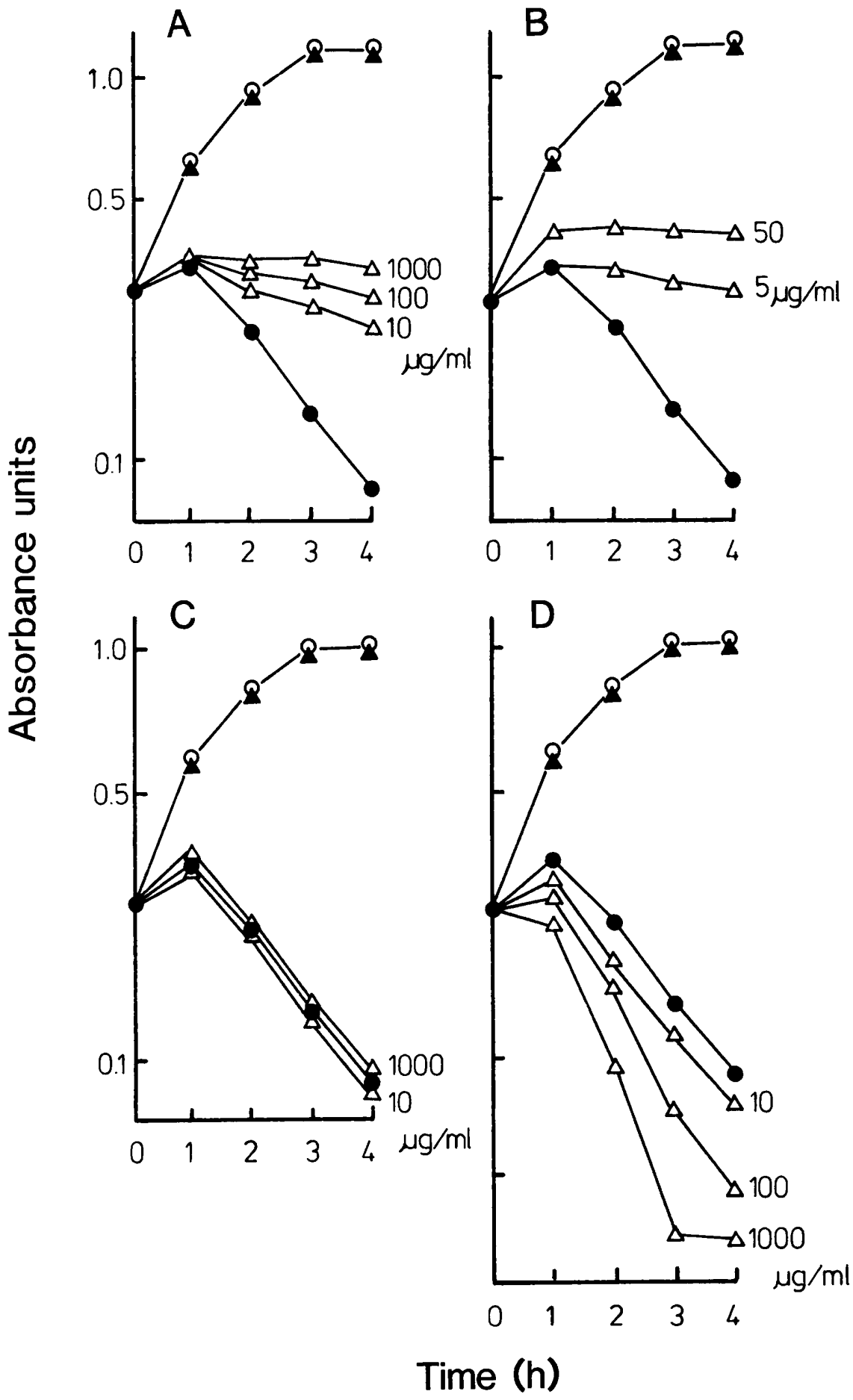

Fig. 1. Effects of heparin (A), dextran sulphate (B), chondroitin sulphates A and C (C), and hyaluronic acid (D) on lysis of $S$. aureus by penicillin. Heparin, dextran sulphate, chondroitin sulphates, and hyaluronic acid were added at the start of the experiment; $1 \mathrm{~h}$ later penicillin was added (time 0 ) to achieve a concentration of $0.1 \mu \mathrm{g} / \mathrm{ml}$. $O=$ control; $\boldsymbol{O}=$ penicillin alone; $\boldsymbol{\Delta}=$ mucopolysaccharides or dextran sulphate alone; $\triangle=$ mucopolysaccharides, or dextran sulphate, and penicillin. 
Table I. Effects of penicillin, heparin, dextran sulphate and hyaluronic acid on viability of $S$. aureus

\begin{tabular}{|c|c|c|}
\hline \multirow[b]{2}{*}{ Additions } & \multicolumn{2}{|c|}{ Viable count (cfu/ml) } \\
\hline & $0 \mathrm{~h}$ & $4 \mathrm{~h}$ \\
\hline None & $2.4 \times 10^{8}$ & $4.3 \times 10^{9}$ \\
\hline Benzylpenicillin $(0 \cdot 1 \mu \mathrm{g} / \mathrm{ml})$ & $2.6 \times 10^{8}$ & $6.5 \times 10^{4}$ \\
\hline Heparin $(1.0 \mathrm{mg} / \mathrm{ml})$ & $3.1 \times 10^{8}$ & $3.2 \times 10^{9}$ \\
\hline \multicolumn{3}{|l|}{ Heparin $(1.0 \mathrm{mg} / \mathrm{ml})$} \\
\hline+ benzylpenicillin $(0.1 \mu \mathrm{g} / \mathrm{ml})$ & $3.1 \times 10^{8}$ & $2.5 \times 10^{5}$ \\
\hline Dextran sulphate $(0.5 \mathrm{mg} / \mathrm{ml})$ & $2.5 \times 10^{8}$ & $3.3 \times 10^{9}$ \\
\hline \multicolumn{3}{|l|}{ Dextran sulphate $(0.5 \mathrm{mg} / \mathrm{ml})$} \\
\hline+ benzylpenicillin $(0.1 \mu \mathrm{g} / \mathrm{ml})$ & $2.5 \times 10^{8}$ & $3.4 \times 10^{5}$ \\
\hline Hyaluronic acid $(1.0 \mathrm{mg} / \mathrm{ml})$ & $2.4 \times 10^{8}$ & $3.5 \times 10^{9}$ \\
\hline \multicolumn{3}{|l|}{ Hyaluronic acid $(1.0 \mathrm{mg} / \mathrm{ml})$} \\
\hline+ benzylpenicillin $(0.1 \mu \mathrm{g} / \mathrm{ml})$ & $2.4 \times 10^{8}$ & $2.0 \times 10^{4}$ \\
\hline
\end{tabular}

heat-killed cells (fig. 2). Autolysis was inhibited by dextran sulphate and accelerated by hyaluronic acid; heparin had no effect (fig. 2). Chondroitin sulphates $A$ and $C$ also had no effect on autolysis (data not shown).

\section{Effects of mucopolysaccharides on autolysin activities}

Extracellular or cell-associated autolysin added to a suspension of $M$. lysodeikticus caused cell lysis (fig. 3). Dextran sulphate markedly inhibited both extracellular and cell-associated autolysin activities against $M$. lysodeikticus. Heparin inhibited autolysin activities at a concentration of $8 \mathrm{mg} / \mathrm{ml}$, but lower concentrations $(\leq 4 \mathrm{mg} / \mathrm{ml})$ had no effect. Hyaluronic acid accelerated autolysin activity.

\section{Effects of mucopolysaccharides on the release of $\left[{ }^{14} \mathrm{C}\right]$-glycerol labelled LTA from $S$. aureus}

More than $90 \%$ of the $\left[{ }^{14} \mathrm{C}\right]$-glycerol labelled material released into the culture supernates was ascertained by the method of Kessler and Shockman (1979) to be polyglycerophosphate derived from LTA. Release of LTA from the untreated control culture was only $20 \%$ of that observed after exposure to penicillin for $30 \mathrm{~min}$ (fig. 4); there was no evidence of cell lysis at this time. Heparin and dextran sulphate inhibited the release of $\left[{ }^{14} \mathrm{C}\right]-$ glycerol-labelled LTA from $S$. aureus cells exposed to penicillin. Addition of heparin or dextran sulphate (final concentration $1 \mathrm{mg} / \mathrm{ml}$ ) reduced the release of $\left[{ }^{14} \mathrm{C}\right]$-glycerol-labelled LTA to $60-70 \%$ of that induced by penicillin alone. In contrast, release

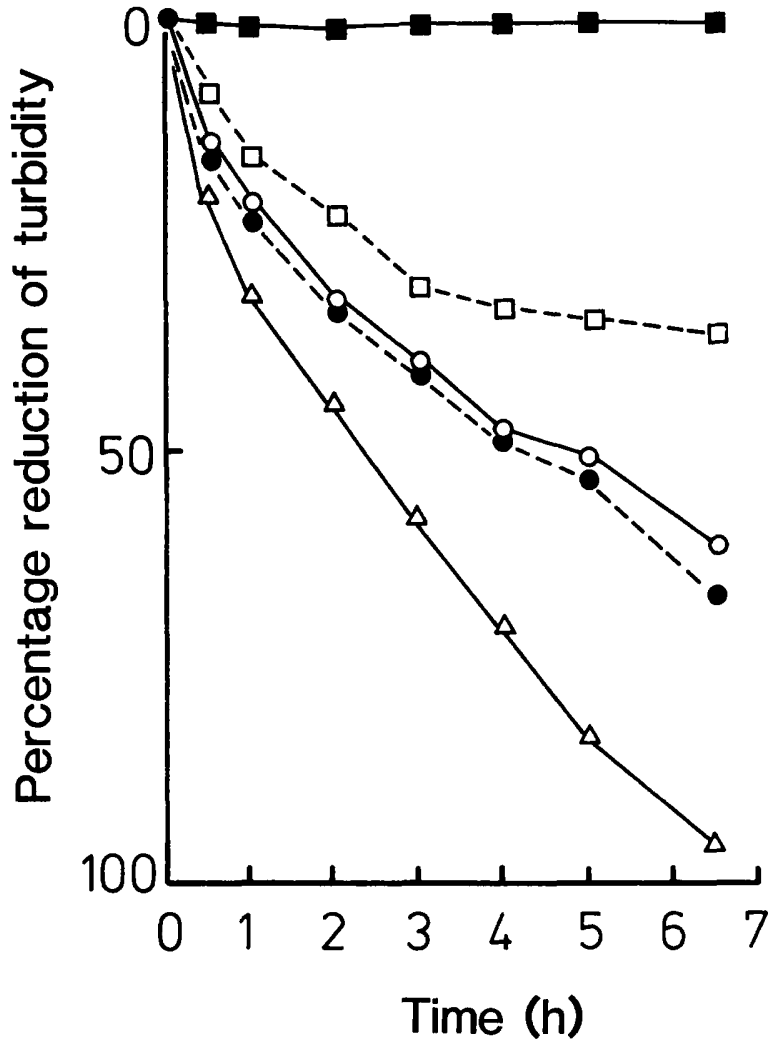

Fig. 2. Effects of heparin, dextran sulphate, and hyaluronic acid on autolysis of $S$. aureus. $=$ control; $O=$ heparin $(1 \mathrm{mg} / \mathrm{ml})$; $\square=$ dextran sulphate $(1 \mathrm{mg} / \mathrm{ml}) ; \triangle=$ hyaluronic acid $(1 \mathrm{mg} /$ $\mathrm{ml}) ; \mathbf{\square}=$ heat-killed cells.

of $\left[{ }^{14} \mathrm{C}\right]$-glycerol-labelled LTA was not influenced by hyaluronic acid.

\section{Combined antimicrobial effect of penicillin with heparin, dextran sulphate or hyaluronic acid}

The presence of heparin or dextran sulphate raised the MIC of penicillin for $S$. aureus. Conversely, the addition of hyaluronic acid lowered the MIC (table II). Heparin, dextran sulphate and hyaluronic acid individually had no influence on bacterial growth.

\section{Discussion}

Lysis of gram-positive bacteria exposed to penicillin is caused by autolytic enzymes, the activity of which is triggered by release of an inhibitor from the bacterial cell wall (Tomasz, 1974; Tomasz and Waks, 1975; Garcia et al., 1982). In S. aureus and other gram-positive bacteria, the inhibitor appears to be LTA (Cleveland et al., 1975, 1976 $a$ and $b$; Höltje and Tomasz, 1975; Suginaka et al., 1979a). Cardiolipin and other phospholipids can also 


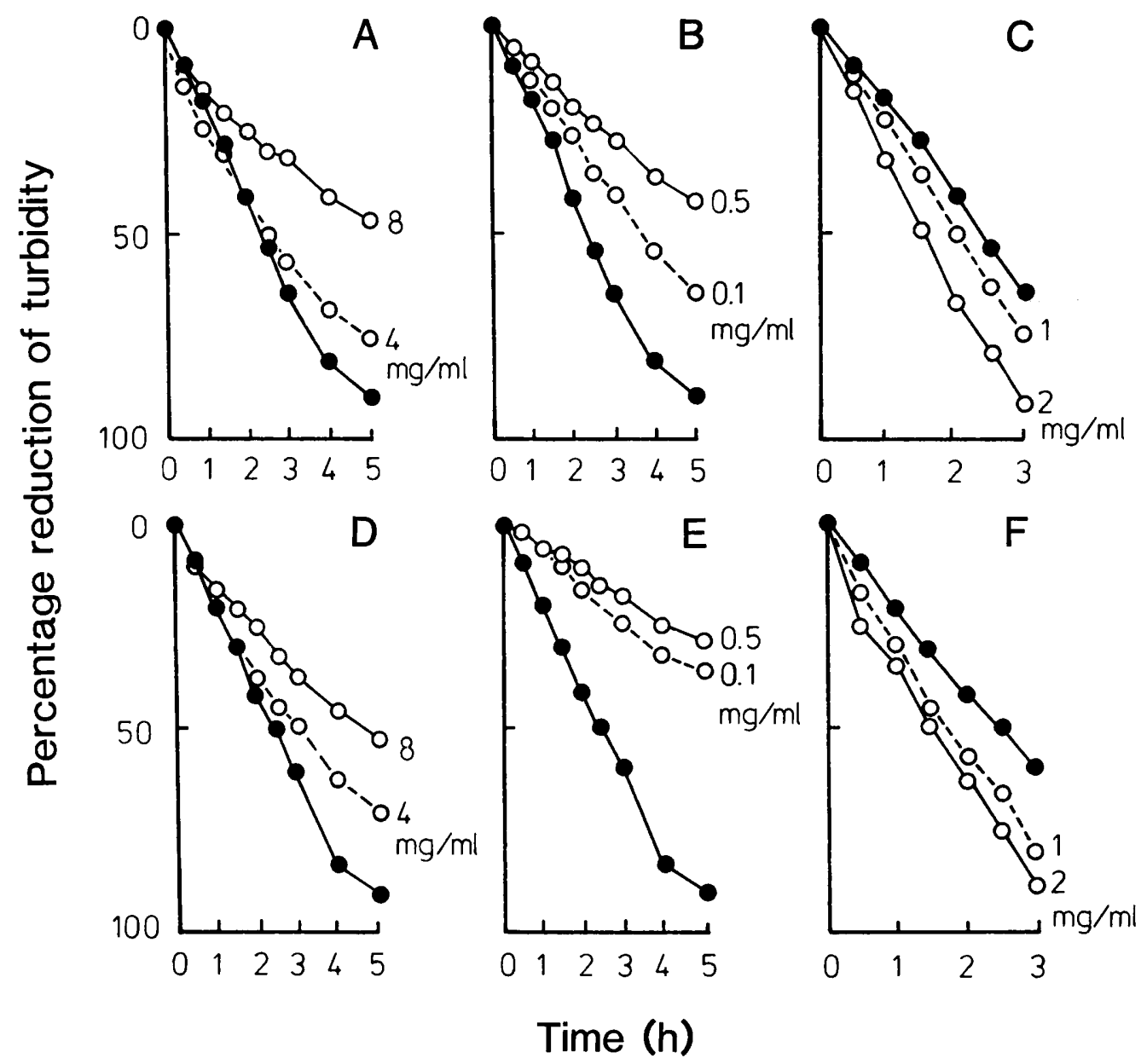

Fig. 3. Percentage reduction of turbidity of $M$. lysodeikticus by extracellular (A, B, C) or cell-associated (D, E, F) autolysins in the absence $(\mathbf{O})$, or presence $(O)$ of heparin $(A, D)$, dextran sulphate $(B, E)$ or hyaluronic acid $(C, F)$.

inhibit autolysin activity in $S$. aureus and Streptococcus faecium (Horne et al., 1977; Suginaka et al., $1979 b)$.

In the present study, heparin and dextran sulphate were found to interfere with the bacteriolytic effect of penicillin on $S$. aureus, whereas hyaluronic acid accelerated the lytic effect. The effects of heparin and dextran sulphate in reducing the fall in turbidity of cultures of $S$. aureus exposed to penicillin might have been exaggerated, because microscopy revealed swelling of the bacterial cells. Similarly, the falls in viable count might have been affected by inhibition of cell separation. Liquoid (sodium polyanethol sulphonate) which, like heparin and dextran sulphate suppresses autolysis of $S$. aureus, also inhibits cell separation (Wecke et al., 1986).
Inhibition of autolysis by dextran sulphate and acceleration of autolysis by hyaluronic acid seemed to occur through direct action on the autolysins. In contrast, inhibition of penicillin-induced lysis by heparin appeared to be due to inhibition of release of LTA. Thus, once release of LTA was initiated by exposure to penicillin, the addition of heparin did not inhibit lysis, whereas dextran sulphate did. Because hyaluronic acid had no effect on LTA release, acceleration of penicillin-induced lysis by this substance presumably resulted from enhancement of autolysin activity.

The finding that hyaluronic acid-enhanced lysis of $S$. aureus by penicillin conflicts with previous reports. Ginsberg et al. $(1976,1982)$ and Ne'eman (1979) reported that hyaluronic acid and other anionic polyelectrolytes markedly inhibited spon- 

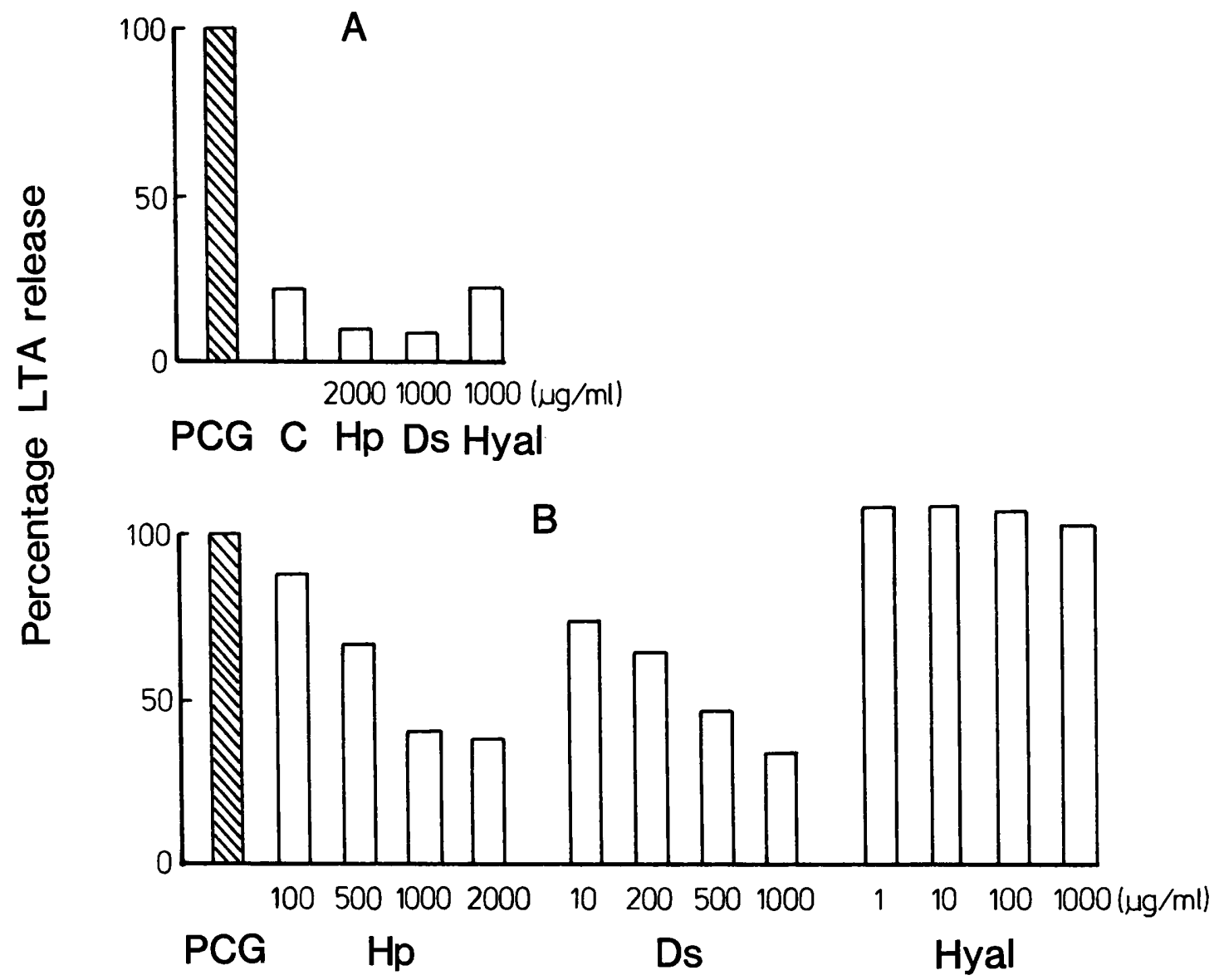

Fig. 4. Effects of heparin (Hp), dextran sulphate (Ds) and hyaluronic acid (Hyal) on the release of $\left[{ }^{14} \mathrm{C}\right]$-glycerol-labelled LTA from $S$. aureus. Data are expressed as percentage LTA released relative to the value for penicillin (PCG; final concentration $0 \cdot 1 \mu \mathrm{g} / \mathrm{ml}$ ) which was arbitrarily assigned a value of $100 \%$. $A=$ LTA release by heparin, dextran sulphate or hyaluronic acid alone. $B=L T A$ released in the presence of penicillin and heparin, dextran sulphate, or hyaluronic acid.

Table II. Combined antibacterial effect of benzylpenicillin with heparin, dextran sulphate, or hyaluronic acid on $S$. aureus.

\begin{tabular}{ll}
\hline \multicolumn{1}{c}{ Addition $(\mu \mathrm{g} / \mathrm{ml})$} & MIC of penicillin $(\mu \mathrm{g} / \mathrm{ml})$ \\
\hline None & $0 \cdot 05$ \\
Heparin & \\
100 & $0 \cdot 10$ \\
500 & $0 \cdot 15$ \\
800 & $0 \cdot 20$ \\
Dextran sulphate & \\
10 & $0 \cdot 10$ \\
40 & $0 \cdot 15$ \\
60 & $0 \cdot 20$ \\
Hyaluronic acid & \\
100 & $0 \cdot 02$ \\
200 & $0 \cdot 015$ \\
300 & $0 \cdot 01$ \\
400 & $0 \cdot 01$ \\
\hline
\end{tabular}

taneous and induced lysis of $S$. aureus, and that staphylococci grown in the presence of anionic polyelectrolytes became highly resistant to lysis triggered by inducers of autolysis. These workers also showed that various cationic substances could activate the autolytic systems of $S$. aureus. The disparity between our results and those of others may reflect differences in the method of triggering bacteriolysis.

Acid mucopolysaccharides are important components of connective tissue; they have a negative charge at neutral $p \mathrm{H}$ and therefore act as anionic polyelectrolytes. Infected inflammatory lesions are rich in these substances. This study has shown that the antibacterial action of penicillin is influenced by several anionic polyelectrolytes and such effects should be taken into account during therapy. This might be particularly important when, for example, heparin is co-administered with penicillin. 


\section{REFERENCES}

Cleveland R F, Höltje J V, Wicken A J, Tomasz A, DaneoMoore L, Shockman G D 1975 Inhibition of bacterial wall lysins by lipoteichoic acids and related compounds. Biochemical and Biophysical Research Communications 67:11281135.

Cleveland R F, Wicken A J, Daneo-Moore L, Shockman G D 1967 a Inhibition of wall autolysis in Streptococcus faecalis by lipoteichoic acid and lipids. Journal of Bacteriology 126: $192-197$.

Cleveland R F, Daneo-Moore L, Wickens A J, Shockman G D $1976 b$ Effect of lipoteichoic acid and lipids on lysis of intact cells of Streptococcus faecalis. Journal of Bacteriology 127: 1582-1584.

Garcia E, Rojo J M, Garcia P, Ronda C, Lopez R, Tomasz A 1982 Preparation of antiserum against the pneumococcal autolysin-inhibition of autolysin activity and some autolytic processes by the antibody. FEMS Microbiology Letters 14: 133-136.

Ginsburg I, Lahav M, Ne'eman N, Duchan Z, Chanes S, Sela MN 1976 The interaction of leukocytes and their hydrolases with bacteria in vitro and in vivo: modification of the bactericidal and bacteriolytic reactions by cationic and anionic macromolecular substances and by anti-inflammatory agents. Agents and Actions 6:292-305.

Ginsburg I, Lahav M, Giesbrecht P 1982 Effect of leukocyte hydrolases on bacteria. XVI. Activation by leukocyte factors and cationic substances of autolytic enzymes in Staphylococcus aureus: modulation by anionic polyelectrolytes in relation to survival of bacteria in inflammatory exudates. Inflammation 6:269-284.

Höltje J V, Tomasz A 1975 Lipoteichoic acid: a specific inhibitor of autolysin activity in pneumococcus. Proceedings of the National Academy of Sciences of the USA 72:1690-1694.

Horne D, Hakenbeck R, Tomasz A 1977 Secretion of lipids induced by inhibition of peptidoglycan synthesis in streptococci. Journal of Bacteriology 132:704-717.

Kessler R E, Shockman G D 1979 Precursor-product relationship of intracellular and extracellular lipoteichoic acids of Streptococcus faecium. Journal of Bacteriology 137: 869-877.

Lowry O H, Rosebrough N J, Farr A L, Randall R J 1951 Protein measurement with the folin phenol reagent. Journal of Biological Chemistry 193: 265-275.

Ne'eman N et al. 1979 Effect of leukocyte hydrolases on bacteria. XIV. Bacteriolytic effects of human sera, synovial fluids, and purulent exudates on Staphylococcus aureus and Streptococcus faecalis: modulation by Cohn's fraction II and by polyelectrolytes. Inflammation 3:379-394.

Rogers H J 1967 Killing of staphylococci by penicillins. Nature 213:31-33.

Rogers H J, Forsberg C W 1971 Role of autolysins in the killing of bacteria by some bactericidal antibiotics. Journal of Bacteriology 108: 1235-1243.

Suginaka H, Shimatani M, Ogawa M, Kotani S 1979a Prevention of penicillin-induced lysis of Staphylococcus aureus by cellular lipoteichoic acid. Journal of Antibiotics 32:73-77.

Suginaka H, Shimatani M, Ohno Y, Yano I 1979b Effects of bacterial lipids and lipoteichoic acid on extracellular autolysin activity from Staphylococcus aureus. FEMS Microbiology Letters 5:353-355.

Tomasz A, Albino A, Zanati E 1970 Multiple antibiotic resistance in a bacterium with suppressed autolytic system. Nature 227: 138-140.

Tomasz A 1974 The role of autolysins in cell death. Annals of the New York Academy of Sciences 235:439-447.

Tomasz A, Waks S 1975 Mechanism of action of penicillin: triggering of the pneumococcal autolytic enzymes by inhibitors of cell wall synthesis. Proceedings of the National Academy of Sciences of the USA 72:4162-4166.

Wecke J, Lahav M, Ginsburg I, Kwa E, Giesbrecht P 1986 Inhibition of wall autolysis of staphylococci by sodium polyanethol sulfonate "Liquoid". Archives of Microbiology 144: 110-115. 